\title{
KELESTARIAN BUDAYA SEBAGAI DASAR DALAM UPAYA PENGEMBANGAN PARIWISATA DI YOGYAKARTA
}

\author{
Disusun oleh \\ Hermawan Prasetyanto, S.Sos. S.ST.Par \\ Dosen Sekolah Tinggi Pariwisata AMPTA Yogyakarta
}

\begin{abstract}
ABSTRAKSI
Global rivalry demands modernization existence at tourism sector. that thing necessary done so that tourist readies to pay a visit and felt to feel at home at city that visited. Consequence from this modernization is builds amount of tourism sector supporting facilities.

Troubleshoot appears when tourism sector development little by little threaten existence and local culture preservation. Inch by inch but certain society will adopted culture moderner that come from outside the culture self.

That thing evoke problem aloof. majority tourist comes to yogyakarta not in the first place to enjoy modern atmosphere, but exactly to know and enjoy atmosphere and local culture. if that looked for modern atmosphere, metropolis like jakarta, surabaya, and batam prepare it. so, if inch by inch local culture is shifted, for certain that is long too long yogyakarta will lose asset to on the market in tourists. $N$ i more specification yogyakarta that can be putted to interesting tourist.

Problem necessary looked for soluasi. tourism development yogyakarta necessary aimed in tourism development berorientasi in culture preservation. to creat tourism development berorientasi in culture preservation, there are some matter that can be goed. first, encouragement returns festifal local culture. second, necessary tourism planology mapping existence. third, give culture local load in special province yogyakarta education curriculum. fourth, revitalisasi palace as culture centre. fifth, tourism development observer team formation.

If success created tourism development that pay attention culture preservation, can be believed that from time to time yogyakarta permanent will can to defend the existence as tourism city.
\end{abstract}

\section{Pendahuluan}

Dunia pariwisata Indonesia sedang mengalami cobaan yang cukup berat. Teror di sejumlah tempat yang secara frontal mengancam sektor pariwisata belum juga terselesaikan. Akibatnya, dunia pariwisata menjadi lesu karena sedikit sekali wisatawan yang berkunjung ke obyek-obyek wisata. Jumlah pengunjung yang sedikit ini membawa efek samping secara berantai mulai dari merosotnya keuntungan sektor bisnis perjalanan wisata, sektor perhotelan, rumah makan, perdagangan, pendapatan asli daerah, dan pada pada akhirnya jumlah pengangguran akan semakin bertambah.

Dalam hubungannya dengan pariwisata di Yogyakarta, ada keuntungan yang dapat dipetik dari berbagai peristiwa pariwisata secara global. Peristiwa teror Bom Bali membawa keuntungan dan harapan bagi sektor pariwisata Yogyakarta di mana diharapkan wisatawan berubah orientasinya dari Bali ke Yogyakarta. Ada dua alasan pokok yang mendukungnya, yaitu faktor keamanan dan faktor tawaran obyek wisata. Yogyakarta seperti halnya Bali menawarkan aset kebudayaan sebagai obyek utama pariwisata. Maka ketika Yogyakarta lebih unggul dalam sektor keamanan diharapkan para wisatawan akan mengalihkan tujuannya ke Yogyakarta.

Permasalahannya sekarang justru terdapat di dalam diri Yogyakarta sendiri. Perkembangan sektor 
pariwisata yang selama ini memberikan keuntungan ekonomis cukup tinggi justru mulai dicemari oleh praktek-praktek mencari keuntungan semata tanpa mengindahkan kekhasan Yogyakarta sebagai kota yang berbudaya tinggi. Keramahtamahan penduduk Yogyakarta berangsurangsur hilang dan digantikan oleh upaya-upaya setengah memaksa yang dilakukan oleh para pemandu wisata dalam mengarahkan wisatawan untuk berbelanja sebanyak mungkin. Harapannya tentu saja pemandu wisata mendapat tips besar dari para pedagang. Sejumlah tempat dibongkar untuk pembangunan hotel berbintang. Sejumlah restoran bercorak asing bermunculan sementara restoran khas Yogyakarta perlahan-lahan tergusur ke daerah pinggiran.

Dalam diri masyarakat sendiri terjadi perubahan pola hidup dan perilaku. Pola hidup dan perilaku sejumlah anggota masyarakat di sekitar obyek wisata menjadi menyimpang dari pola hidup dan perilaku budaya aslinya. Budaya makan di KFC, Pizza Hut, Dunkin Donat, Kafe, dan sejenisnya sudah merasuki kehidupan sehari-hari generasi muda kita. Bahkan banyak di antara mereka rela mengorbankan etika dan sopan santun demi keuntungan finansial.

Dalam pandangan Emha Ainun Nadjib (1994:160), Yogyakarta kini sepertinya sedang sentimental dan murung karena generasi mudanya berduyun-duyun meninggalkan kebudayaannya sendiri. Rasa sentimentil dan murung itu justru timbul karena kebanggannya yang begitu besar akan identitas dirinya yang termasyur sebagai pusat kebudayaan Jawa yang adiluhung.

Jika kecenderungan-kecen derungan yang terjadi di Yogyakarta tersebut tidak segera diatasi, ada kemungkinan sektor pariwisata Yogyakarta akan semakin terpinggirkan dan kalah bersaing dengan daerah-daerah lain. Karena keuntungan yang cukup besar, daerahdaerah lain berlomba menawarkan sektor pariwisatanya kepada para wisatawan baik asing maupun dalam negeri. Sektor pariwisata diharapkan menjadi andalan utama semua daerah dalam memperoleh pendapatan asli daerah (PAD). Untuk itu perlu segera dipikirkan dan dicari solusinya agar pengembangan pariwisata di Yogyakarta tetap mampu menjawab tantangan zaman sehingga sektor pariwisata tetap eksis dan mampu memberikan sumbangan besar dalam pencapaian kesejahteraan masyarakat Yogyakarta.

\section{Potensi-potensi Pengembangan Yogyakarta}

Otonomi yang dilakukan di negara kita akan mendorong setiap daerah untuk mengekploitasi sumbersumber pendapatan daerahnya semaksimal mungkin. Hal ini juga dilakukan oleh Yogyakarta. Terdapat empat potensi daerah yang cukup menarik untuk terus dikembangkan.

Pertama, Yogyakarta sebagai kota pendidikan. Sebutan Yogyakarta sebagai kota pendidikan mengacu pada jumlah lembaga pendidikan dan kualitas pendidikan di Yogyakarta. 
Tidak terhitung jumlah lembaga pendidikan mulai pendidikan prasekolah sampai dengan perguruan tinggi. Kualitas lulusannya pun telah mendapat pengakuan berbagai pihak. Potensi Yogyakarta sebagai kota pendidikan ini menyebabkan banyak sekali generasi muda dari berbagai daerah yang ingin meneruskan pendidikannya di Yogyakarta terutama pendidikan menengah (SMU/SMK) dan pendidikan tinggi. Kedatangan para pelajar dan mahasiswa tersebut tentu saja memunculkan kegiatan bisnis seperti rumah makan, tempat tinggal, perdagangan buku, rental, alatalat kost, dan tempat hiburan. Jika terkelola dengan baik, predikat kota pendidikan akan mampu memberikan kontribusi terhadap pendapatan daerah, yang pada akhirnya mampu meningkatkan kesejahteraan penduduk Yogyakarta.

Kedua, Yogyakarta sebagai kota budaya. Predikat kota budaya yang diberikan pada Yogyakarta mengacu pada keberadaan Kraton Yogyakarta yang dipandang sebagai pusat kebudayaan Jawa. Di samping itu banyak sekali budayawan dan sastrawan yang bertempat tinggal di Yogyakarta. Predikat kota budaya juga didukung oleh berbagai kegiatan kebudayaan seperti sekatenan dan labuhan. Potensi-potensi budaya ini jika dikelola dengan baik akan menjadi aset pariwisata yang cukup handal dan mampu menarik wisatawan untuk datang ke Yogyakarta.

Ketiga, Yogyakarta sebagai kota pariwisata. Predikat kota pariwisata diberikan pada Yogyakarta karena sudah lama kota Yogyakarta menjadi daerah tujuan pariwisata baik wisatawan domestik maupun mancanegara. Hampir setiap hari terutama pada saat musim liburan, banyak sekali wisatawan yang mengunjungi Prambanan, Kraton, Pantai Parangtritis, dan Malioboro untuk melakukan perjalanan wisata baik wisata umum maupun studi wisata. Jika predikat kota pariwisata ini tetap dipertahankan dan ditambah lagi dengan penyempurnaan berbagai sektor pariwisata, dapat dipastikan bahwa Yogyakarta akan mampu bersaing dengan daerah-daerah lain dalam upaya pembagunan daerah.

Keempat, Yogyakarta sebagai kota perjuangan. Predikat kota perjuangan diberikan pada Yogyakarta dengan mengacu pada berbagai peristiwa sejarah perjuangan bangsa Indonesia yang terjadi di Yogyakarta. Sejumlah peristiwa sejarah pada akhirnya meninggalkan kenangan berupa tempat-tempat bersejarah, museum perjuangan, rute perjalanan gerilya, dan makam para pahlawan. Jika aset ini bisa dikelola dengan baik, Yogyakarta dapat menjadikan peninggalan-peninggalan itu sebagai sarana pengembangan Yogyakarta terutama untuk pengembangan sektor pariwisata.

Pentingnya Pelestarian Kebu dayaan dalam Pengembangan Yogyakarta

Pengembangan berbagai sektor kehidupan masyarakat Yogyakarta membawa pengaruh cukup besar dalam diri masyarakat. Pengaruh tersebut langsung menyentuh pada identitas 
dasar masyarakat, yaitu sisi kebudayaan. Secara perlahan-lahan tetapi pasti masyarakat terpengaruh oleh kebudayaan pendatang yang mereka anggap lebih maju. Kebudayaan pendatang tersebut bukan saja berasal dari luar negeri yang dibawa oleh wisatawan asing, melainkan juga dari dalam negeri yang dibawa oleh wisatawan dalam negeri maupun para pelajar dari berbagai daerah.

Menurut Soedjatmoko (1988:44) perkembangan modernisasi yang seperti itu membawa masalah tersendiri ketika masyarakat telah kehilangan nilai-nilai lama dan cara lama sementara nilai lama dan cara baru belum mencapai kristalisasinya. Hal ini akan menimbulkan kekhawatiran akan terjadinya krisis identitas kepribadian dalam diri masyarakat.

Dalam kaitannya dengan perkembangan modernisasi di Yogyakarta, apabila tidak segera mendapat respon, dapat dimungkinkan terjadi krisis identitas dalam diri masyarakat terutama penduduk asli Yogyakarta yang selama bertahuntahun memegang teguh nilai-nilai kebudayaan tradisional.. Derasnya pengaruh luar baik kebudayaan asing maupun kebudayaan daerah lain akan menimbulkan tranformasi budaya yang pada akhirnya akan menghasilkan generasi-generasi yang multikultur. Menurut Suyatno Kartodirdjo (1992:145), ada empat masalah yang timbul sebagai akibat tranformasi budaya tersebut, yaitu masalah ketahanan budaya dan konflik nilai, masalah komersialisasi budaya, masalah materialisme dan konsumerisme, dan masalah konflik sosial.

Dalam kaitannya dengan pengembangan pariwisata di Yogyakarta, masalah komersialisasi budaya akan menjadi masalah penting. Pemikiran-pemikiran berbagai pihak hanya difokuskan pada bagaimana memperoleh keuntungan finansial dari sektor kebudayaan. Akibatnya, motivasi utamanya bukan lagi memelihara dan melestarikan kebudayaan budaya yang dimilikinya melainkan pada pertimbangan bisnis semata. Jika hal itu terjadi, kebudayaan bisa dimanipulasi demi kepentingan bisnis. Bahkan jika tidak diperhatikan secara sungguh-sungguh hal itu akan mengakibatkan munculnya budaya baru yang tidak berakar pada kepribadian dan identitas bangsa. Menurut Kartodirjo (1992:146) transformasi yang tidak berakar pada kepribadian dan identitas bangsa akan menghasilkan budaya modern yang cenderung akan menelan jenis budayabudaya tradisional yang telah terbukti mempunyai nilai-nilai pencerminan kepribadian bangsa dan identitas bangsa.

Jika krisis sektor kebudayaan ini secara terus menerus dialami oleh masyarakat, dapat dipastikan bahwa tidak akan ada lagi pewarisan kebudayaan dari generasi tua kepada generasi muda. Kalaupun ada, kebudayaan yang diwariskan tersebut akan mengalami reduksi yang cukup hebat. Bisa jadi bentuk fisik kebudayaannya terwariskan tetapi roh- 
nya sudah hilang. Misalnya saja dari segi berpakaian. Mungkin saja generasi muda terlihat gagah ketika mengenakan pakaian adat Jawa. Namun perilaku dan unggahungguhnya tidak ada.

Upaya pelestarian kebudayaan ini menjadi sangat penting untuk dilakukan karena fakta di lapangan menunjukkan bahwa para wisatawan sangat tertarik dengan bidang budaya. Ketertarikan wisatawan pada bidang budaya dapat diketahui dari berbagai indikator.

Pertama, banyaknya wisatawan dan para pelajar yang melakukan studi wisata yang mengunjungi Kraton Yogyakarta. Keingintahuan wisatawan terhadap Kraton Yogyakarta dilandasi oleh keingintahuan akan pusat kebudayaan Jawa. Sementara itu keinginan para pelajar untuk melakukan studi wisata di Yogyakarta sedikit banyak didasari oleh informasi dalam pembelajaran di mana Kraton Yogyakara merupakan bagian dari sejarah kerajaan yang sampai sekarang masih eksis keberadaannya.

Kedua, banyaknya wisatawan yang tertarik membeli benda-benda tradisional khas. Benda-benda khas yang mencerminkan kebudayaan Jawa seperti keris, kain batik, blangkon, kuda kepang sangat digemari oleh para wisatawan khususnya wisatawan mancanegara. Ketertarikan untuk membeli ini kemungkinan besar dilandasi oleh keingintahuan lebih lanjut akan kebudayaan Jawa.

Dalam jangka panjang, jika masih tetap ingin eksis dalam berbagai bidang, sektor kebudayaan perlu mendapat perhatian lebih dalam pembangunan Yogyakarta. Sektor pendidikan juga akan ditentukan oleh kemampuan masyarakat Yogyakarta da la m m e pertahankan keramahtamahan dan etika kehidupan bermasyarakat. Jika pada akhirnya masyarakat Yogyakarta hanya terjebak pada masalah keuntungan bisnis, tingkat kenyamanan dan keamanan para pelajar terusik. Dan pada akhirnya secara perlahan-lahan banyak orangtua yang akan berpikir panjang untuk menyekolahkan anaknya di Yogyakurta. Sektor pariwisata pada akhirnya sangat ditentukan oleh aset budaya yang dapat ditawarkan pada para wisatawan. Fasilitas yang lengkap, promosi yang gencar, dan pengalokasian dana untuk membangunan sarana fisik pariwisata akan terkesan sia-sia ketika Yogyakarta tidak lagi memiliki aset kebudayaan sebagai andalan utama obyek pariwisata.

Berhubung sektor kebudayaan merupakan sektor yang sangat penting dalam pengembangan pariwisata di Yogyakarta, penyelamatan dan pelestarian budaya lokal perlu dilakukan. Jika penyelamatan dan pelestarian budaya lokal ini dapat dilakukan, Yogyakarta akan mampu bersaing dengan negara-negara lain yang maju dan mempunyai komitmen untuk mengembangkan pariwisata budaya seperti Bali, Korea, Cina, dan Jepang. Namun, jika sektor ini justru tidak terperhatikan, dan fokus pengembangan hanya pada pembangunan sarana dan prasarana fisik, lama kelamaan para wisatawan 
akan bosan untuk berkunjung ke Yogyakarta.

\section{Pengembangan Pariwisata Berori- entasi Pellestarian Budaya}

Permasalahan pokok yang kiranya perlu dicari jalan keluarnya adalah b a ga im a n k it a ma m p mengembangkan pariwisata yang berorientasi pada pelestarian budaya. Dalam hal ini ada beberapa hal yang sekiranya dapat dipertimbangkan sebagai alternatif pengembangan pariwisata yang berorientasi pada pelestarian budaya.

Pertama, menggalakkan kembali berbagai festifal kebudayaan lokal. Seperti diketahui, Yogyakarta memiliki berbagai kegiatan kebudayaan lokal seperti kirab pusaka Tunggul Wulung di kecamatan Minggir, ritual bekakak di kecamatan Gamping, dan sekatenan di Alun-alun Utara. Jika dikemas secara baik dalam bentuk festifal kebudayaan, bentuk-bentuk kegiatan kebudayaan lokal tersebut akan menghasilkan dua keuntungan sekaligus. Pada satu sisi festifal tersebut memiliki nilai komersiil untuk pariwisata dan pada sisi lain memiliki nilai pelestarian kebudayaan. Masyarakat akan bersemangat lagi untuk menggali potensi kebudayaan setempat seperti upacara wiwitan (memulai panen), jatilan, tayub, dolanan, dan potensi industri setempat untuk diikutsertakan dalam festifal tersebut. Para sesepuh masyarakat akan berusaha menggali kembali identitas budaya setempat untuk diwariskan pada generasi muda, dan generasi muda memiliki media untuk mengekspresikannya dalam festifal tersebut.

Ada beberapa cara yang dapat dilakukan pihak-pihak terkait untuk menggalakkan kembali festifal kebudayaan lokal. Salahsatu di antaranya adalah dengan menggalakan promosi pariwisata untuk festifalfestifal tersebut. Anggaran promosi pariwisata tersebut sebenarnya hanya sebagai sarana pemicu untuk menggali sumber dana lain seperti swadaya masyarakat, sponsor, dan para donatur. Jika tersedia anggaran rutin untuk kegiatan semacam itu, dapat diyakini bahwa festifal kebudayaan lokal akan berjalan secara rutin. Cara lain adalah dengan menjadwalkan peristiwaperistiwa tersebut dalam agenda pariwisata daerah. Kegiatan yang teragendakan dengan baik akan memberikan jaminan bahwa sebuah festifal kebudayaan tidak akan kekurangan pengunjung. Antusiasme pengunjung akan memberikan semangat tersendiri bagi penduduk setempat untuk lebih bekerja keras lagi dalam menyajikan potensi kebudayaan daerahnya sendiri. Jika sudah demikian, sektor pariwisata dapat berkembang dengan baik dan kebudayaan setempat dapat tetap terpelihara.

Kedua, perlunya pemetaan tata ruang pariwisata. Jika kita memperhatikan permasalahan pariwisata di Yogyakarta, dapat diketahui bahwa akar permasalahan krisis kebudayaan terjadi karena kurang tertatanya ruang pariwisata di Yogyakarta. Kawasan Kraton (alunalun utara) yang dijadikan areal parkir bus-bus pariwisata mengakibatkan 
lingkungan kraton tereduksi sedemikian rupa sehingga tidak lagi menampakkan kekhasannya sebagai pusat kebudayaan Jawa. Komplek perbelanjaan souvenir yang diletakkan bersebelahan dengan kraton sedikit demi sedikit menghilangkan sikap dasar orang berbudaya Jawa yang dikenal sebagai orang yang ramah dan tanpa pamrih. Gudeg Plengkung Wijilan menjadi terkesan terpinggirkan karena penataan letak yang kurang baik sehingga dalam perkembangan selanjutnya kawasan plengkung wijilan tidak terjamah oleh para wisatawan.

Jika tata ruang pariwisata tersebut tidak segera dibenahi, pelestarian kebudayaan lama kelamaan akan terkorbankan demi kepentingan finansial pariwisata. Dan pada akhirnya, kegiatan kepariwisataan di Yogyakarta akan kehilangan identitas dasarnya sebagai pariwisata yang mengandalkan diri pada potensi kebudayaan. Oleh sebab itu, pihakpihak terkait perlu segera merumuskan pemetaan tata ruang pariwisata. Jika tata ruang pariwisata dapat dipetakan dengan matang, sektor pariwisata akan berkembang dengan baik dan kebudayaan lokal tetap dapat terjaga.

Ketiga, perlu dicantumkannya pendidikan kebudayaan dalam kurikulum pendidikan di Yogyakarta. Masalah krisis kebudayaan di Yogyakarta ini di samping merupakan efek modernisasi juga dipengaruhi oleh mentalitas generasi mudanya. Generasi muda Yogyakarta lebih senang mempelajari kebudayaan-kebudayaan asing daripada kebudayaannya sendiri. Jika hal itu berlangsung terus menerus dapat dimungkinkan terjadi generasi yang antipati terhadap budaya nenek moyangnya sendiri.

Salahsatu jalur untuk memper baiki mentalitas generasi muda itu adalah melalui pendidikan. Slamet Sutrisna (1992:147) mengatakan bahwa perubahan kebudayaan, (termasuk di dalamnya adalah mentalitas manusia, tidak hanya melibatkan sistem nomatif tetapi juga melibakkan sistem kognitif. Dalam hubungannya dengam masyarakat Indonesia yang sedang membangun, budaya keilmuan harus dikembangkan sebagaimana mestinya. Dengan demikian, pengembangan dan pelestarian budaya perlu dihubungkan dengan proses pendidikan bagi generasi penerusnya.

Cara yang paling efektif untuk pembinaan kebudayaan generasi muda dalam kerangka otonomi daerah adalah dengan memasukkan muatan pendidikan kebudayaan khas Yogyakarta dalam kurikulum pendidikan di Yogyakarta. Muatan lokal semacam ini akan menghasilkan efek berantai yang positif yang pada akhirnya akan menguntungkan sektor pariwisata dan sektor pelestarian kebudayaan. Para siswa yang berasal dari Yogyakarta akan memiliki sikap positif terhadap kebudayaannya sendiri. Sikap positif ini akan menghasilkan daya tahan untuk tidak begitu saja terpengaruh oleh budaya asing. Sedangkan para siswa yang berasal dari luar Yogyakarta akan memiliki pengetahuan tentang kebudayaan local dan dapat diyakini bahwa mereka akan mengko 
munikasikannya pada teman-temannya di daerah asalnya. Maka dalam jangka panjang sektor pariwisata akan berkembang dan kebudayaan lokal akan terpelihara.

Keempat, perlunya revitalisasi kraton sebagai pusat kebudayaan. Sebagian besar orang berkeyakinan bahwa kraton merupakan pusat kebudayaan. Sebagai pusat kebudayaan, banyak sekali tugas yang diemban oleh kraton, termasuk memelihara keluhuran budaya warisan nenek moyang. Akhir-akhir ini karena perkembangan zaman dan kepentingan pariwisata, kawasan kraton cenderung diperlakukan sebagai obyek wisata berkategori museum. Pengunjung yang datang ke kraton dan pagelaran lebih banyak disuguhi benda-benda peninggalan sejarah beserta penjelasan terperinci dari para pemandu wisata.

Jika hal tersebut berlangsung secara terus menerus, fungsi kraton sebagai pusat kebudayaan akan hilang. Jika fungsi tersebut hilang, tidak ada lagi lembaga masyarakat yang bertugas menjaga kelestarian dan keluhuran kebudayaan nenek moyang. Jika hal tersebut terjadi, lama kelamaan kebudayaan local akan hilang dan hanya bisa ditemukan sebagai sebuah prasasti di museum. Dan jika hal itu terjadi, pada dasarnya kebudayaan telah mati karena tidak lagi dimiliki oleh masyarakat.

Oleh sebab itu, perlu dilakukan revitalisasi kraton Yogyakarta sebagai pusat kebudayaan. Kegiatan-kegiatan kebudayaan, pemasyarakatan kebudayaan, penggalian kembali kebudayaan, dan berbagai kegiatan pendukung perlu dipelopori oleh kraton. Dengan demikian, fungsi kraton bukan sekedar sebagai prasasti kebudayaan melainkan lebih sebagai pelaku kebudayaan yang memiliki tanggung jawab utama dalam memelihara nilai-nilai luhur budaya lokal.

Dalam kaitannya dengan peranan kraton dalam mempertahankan kekhasan budaya Yogyakarta, ada baiknya kita simak pendapat dari P.J. Suwarno (1992). Beliau mengatakan bahwa Sultan yang memegang kekuasaan kharismatik, tradisional, dan legal-rasional menggunakan kekuasaan itu secara bijaksana untuk mentransformasikan Yogyakarta dari tradisional ke modern tanpa menghancurkan tradisi, tetapi menyeleksinya untuk dimanfaatkan dalam modernisasi Yogyakarta. Dengan demikian, Kraton Yogyakarta perlu memfungsikan diri sebagai pusat transformasi kebudayaan sehingga proses tranformasinya tidak lepas dari nilai-nilai luhur kebudayaan Jawa.

Kelima, pembentukan tim pemantau pengembangan pariwisata. Pada akhirnya, ketika kita dihadapkan pada penataan berbagai kepentingan, diperlukan adanya tim yang bertugas melakukan pemantauan atas pengembangan pariwisata di Yogyakarta. Tim pemantau ini bertugas untuk menciptakan keselarasan pembangunan pariwisata di Yogyakarta agar berbagai kepentingan dapat terakomodasikan tanpa ada yang dirugikan. Kepentingan pelestarian kebudayaan akan terkesan sia-sia jika harus mengorbankan kepentingan 
ekonomis masyarakat. Kepentingan pariwisata akan merugikan jika harus mengorbankan kepentingan pelstarian budaya dan pendidikan. Karena menyangkut berbagai kepentingan, sebaiknya tim ini berasal dari Dinas terkait berbagai elemen masyarakat, termasuk di dalamnya para pelaku kebudayaan (budayawan dan para sesepuh). Dengan demikian pertimbangan-pertimbangan lebih obyektif.

Jika tim ini terbentuk dapat diyakini bahwa pengembangan sektor pariwisata di Yogyakarta akan lebih terarah dan tidak membuahkan korban sektor lain seperti sektor pendidikan dan pelestarian budaya. Dan jika sektor pariwisata berkembang dengan baik, daya tahan dan daya saing kepariwisataan di Yogyakarta akan semakin kuat.

\section{Penutup}

Pengembangan pariwisata dengan berorientasi pada pelestarian kebudayaan tampaknya merupakan kebutuhan mendesak bagi kota Yogyakarta. Sebelum terlanjur mengalami krisis kebudayaan akibat pengembangan pariwisata yang terlalu beroientasi pada bisnis semata, pihakpihak terkait di Yogyakarta perlu melakukan pembenahan. Dibutuhkan kerja keras dan kerelaan berbagai pihak untuk mengalah dan berpikir holistic agar tercapai pengembangan pariwisata yang memiliki daya tahan tinggi di masa-masa mendatang.

\section{Daftar Pustaka}

Bratawidjaja, Thomas Wiyasa. 2000. Upacara Tradisional Masyarakat Jawa. Jakarta : Pustaka Sinar Harapan.

B. Soelarto. 1993. Garebeg di Kesultanan Yogyakarta. Yogyakarta: Kanisius.

Kartodirdjo, Suyatno. 1992. "Tranformasi Budaya dalam Pembangun" dalam Tantangan Kemanusian Universal. Yogyakarta: Kanisius

Nadjib, Emha Ainun. 1994. Indonesia Bagian dari Desa Saya. Yogyakarta : SiPress.

Nusantara, A.Ariobimo. ed. 1999. Sri Sultan Hamengku Buwono X: Meneguhkan Tahta untuk Rakyat. Jakarta : Grasindo bekerja sama dengan Harian Bernas.

Roem, Mohamad, dkk. 1982. Tahta Untuk Rakyat : Celah-celah Kehidupan Sultan Hamengkubuwono IX. Jakarta: PT. Gramedia.

Soedjatmoko. 1988. Etika Pembebasan. Jakarta: LP3ES.

Suwarno, P.J. 1992. "Belajar dari Sejarah Yogyakarta untuk Memasuki Era Globalisasi" dalam Tantangan Kemanusiaan Universal. Yogyakarta: Kanisius.

Tnunay, Tontje. 1991. Yogyakarta Potensi Wisata. Klaten : CV. Sahabat. 